\title{
Promotions to increase lower-fat food choices among students in secondary schools: description and outcomes of TACOS (Trying Alternative Cafeteria Options in Schools)
}

\author{
Jayne A Fulkerson*, Simone A French, Mary Story, Helen Nelson and Peter J Hannan \\ Division of Epidemiology, University of Minnesota, 1300 South Second Street, Suite 300, Minneapolis, \\ MN 55454-1015, USA
}

Submitted 5 August 2003: Accepted 13 November 2003

\begin{abstract}
Objectives: (1) To describe promotional activities, particularly student-led, targeting lower-fat à la carte foods that were conducted in secondary schools; and (2) to describe the relationships between the number and duration of total promotional activities for lower-fat à la carte foods and cafeteria sales of such foods over two years. Design: Promotional activities were implemented in schools that were randomised to the intervention condition of a larger, two-year, school-based, randomised, controlled nutrition intervention trial.

Setting: Ten Minnesota secondary schools.

Subjects: Students and school faculty, school food-service and research staff (measured at the school level).

Results: Over two years, 181 promotions were implemented $(n=49$ in Year 1 and $n=132$ in Year 2). In Year 1, the number of promotions conducted in schools was significantly associated with percentage lower-fat food sales. In Year 2, the duration of promotions was significantly associated with percentage lower-fat food sales.

Conclusions: Collaborative efforts among students, school food-service staff and research staff can be successful in implementing a large number of nutrition-related, school-wide promotional activities. These efforts can increase the sales of lower-fat foods in à la carte areas of school cafeterias.
\end{abstract}

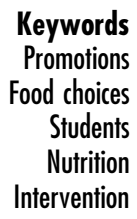

Keywords

Promotions

Students

Nutrition

ntervention
Peer-led activities have been implemented in previous school-based health promotion programmes to reduce substance use ${ }^{1-5}$, prevent HIV/AIDS ${ }^{6}$ and reduce violence ${ }^{7}$. The rationale for using peers as educators stems from the hypothesised importance of social influence in adolescence as outlined in social learning theory ${ }^{8,9}$. Social learning theory approaches to behaviour change focus on changes in social interaction, norms and environmental factors ${ }^{10}$. Peer education programmes change social interactions and norms based on the assumption that adolescents are influenced by the attitudes and behaviours of their friends ${ }^{11}$. Promotion of health behaviour change through peer-led activities provides modelling of healthy behaviours from their peers, and gives adolescent peer leaders decision-making powers and responsibilities ${ }^{1}$. Moreover, changing peer norms surrounding the targeted behaviour is more likely to be accomplished when adolescents play a key role in the change process. In fact, there is evidence that peer-led health education is at least as effective as adult-led health education ${ }^{3,5,12-14}$.

Typically, peer leaders are selected by their peers and trained to lead activities ${ }^{15,16}$; however, some promotion programmes have implemented activities with volunteer peer leaders ${ }^{17}$. Regardless of the recruitment process, training peer leaders usually includes teaching technical expertise and knowledge of the importance of their role in behaviour change, and generating a sense of commitment and enthusiasm for the goals of the project ${ }^{15}$.

School-based nutrition intervention programmes often employ nutrition education as the main focus of the intervention $^{18}$, or they work directly with food-service providers to modify the preparation of foods included in the national school lunch programme ${ }^{19-22}$. Few nutrition intervention studies have implemented peer- or studentled activities ${ }^{23,24}$, even though evidence supports the idea that peer influence is important in the development of adolescents' food habits and other health behaviours ${ }^{25}$. During adolescence, peer influence and the broader social environment are associated with eating foods high in saturated fat and with fruit and vegetable intake ${ }^{26}$.

TACOS (Trying Alternative Cafeteria Options in Schools) was a two-year, group-randomised, school-based nutrition intervention $\operatorname{trial}^{27}$. The purpose of the present report is to:

1. describe the promotional activities, particularly student-led, used to increase lower-fat à la carte food 
choices among students in secondary schools as part of the TACOS study; and

2. evaluate associations between the number and duration of total promotional activities in relation to changes in sales of lower-fat à la carte foods in the school cafeteria.

It was hypothesised that a greater number and longer duration of total promotional activities would increase student sales of lower-fat foods in the school cafeteria.

\section{Methods}

\section{Study design}

Twenty secondary schools in the Minneapolis/St. Paul area, Minnesota, agreed to take part in TACOS ${ }^{27}$. Schools were randomly assigned to the intervention programme or to a no-intervention control group. The 10 schools that were randomised to the intervention programme are the focus of the present report. The 10 schools were predominantly suburban in location and ranged in enrolment from 812 to 3157 students (median 1493). On average, $10 \%$ of students were non-white (median $7 \%$; range $3-23 \%$ ) and $6 \%$ were eligible for free/reduced lunch (median 6.5\%; range 2-24\%). All 10 schools participated in the National School Lunch Program run by the US Department of Agriculture ${ }^{28}$.

The goal of the TACOS study was to increase the sales and choices of lower-fat foods in the à la carte areas of high-school cafeterias by increasing the availability of lower-fat food in the cafeterias and through school-wide, student-based promotions. The purpose of the student promotion programme was to increase student awareness of the lower-fat food choices in the à la carte areas and to promote sales of lower-fat à la carte foods. Student groups were recruited to plan, organise and implement promotional activities for lower-fat à la carte foods in the school cafeteria. Research staff and food-service staff served as facilitators of the student groups' promotional activities. The promotion programme was ongoing throughout the two academic years. One of the novel aspects of the promotion component of TACOS was the linkage of several components of an integrated model for comprehensive school-based nutrition education and services $^{29}$, including school food-service, classroom nutrition education and the food environment of schools.

\section{Establishing student groups}

Each group consisted of at least one faculty advisor, a research staff member and students. The Promotions Coordinator was a full-time research staff person who recruited student groups and faculty advisors in each of the 10 intervention schools. The Promotions Co-ordinator recruited faculty advisors by contacting teachers of specific subject areas or student group organisations; asking school administrators, food-service administrators
Table 1 Number of school faculty members who participated in organising promotional activities

\begin{tabular}{lcc}
\hline & Year 1 & Year 2 \\
\hline Health teachers & 6 & 5 \\
Physical education teachers & 2 & 3 \\
Marketing teachers & 4 & 3 \\
Family and consumer science (FCS) teachers & 2 & 1 \\
English teachers & 1 & 0 \\
Student newspaper advisors & 2 & 3 \\
Student council advisors & 2 & 1 \\
Future Leaders of America (FLA) advisors & 1 & 1 \\
Drama programme advisors & 0 & 2 \\
Total & 20 & 19 \\
\hline
\end{tabular}

or teachers to suggest potential faculty members who might be interested in the TACOS project; inviting faculty members to participate in the study after brief presentations at faculty/staff meetings; and networking with school staff known to the research team. Several phone calls were usually needed to contact potential faculty liaisons, and in most cases a face-to-face meeting was scheduled. At the meeting, information was provided about the study, and possible options for student involvement and the financial incentive were explained. At least one faculty advisor or teacher at each school was recruited to serve as the school liaison to establish a working relationship between the TACOS staff and student groups/classes. As shown in Table 1, research staff worked with 20 school faculty advisors in Year 1 and 19 school faculty advisors in Year 2 to implement promotional activities. Each school liaison was given a menu of promotional activities (see Table 2). An initial meeting with faculty advisors and recruited students was conducted to select the promotional activity to implement based on student interest and feasibility. After a specific promotion was selected, a detailed plan was developed.

Students were recruited by research staff for participation in TACOS promotions through the school faculty and fliers disseminated in registration packets, course schedule packets, hand-outs, at faculty meetings, at Parent-Teacher Association and other parent meetings, at student group meetings, and during class presentations. As shown in Table 3, student groups involved in TACOS promotions were from a wide variety of classes and student organisations.

Monetary incentives were offered to student groups who participated in the promotional programme; the amount of the incentives varied by promotion type, duration and complexity (range \$25-300). All incentive cheques were given to the school faculty person working with the student groups.

\section{Student training}

Research staff provided oversight of activities in several ways: initial training meetings, technical visits, review of materials, event observations and evaluation follow-up visits. All promotional programme components were 
Table 2 Descriptions of promotional activities

\begin{tabular}{|c|c|}
\hline Promotion type & Promotion description \\
\hline Media campaign & $\begin{array}{l}\text { Provided students with an opportunity to apply video, television (TV), internet and } \\
\text { news-writing skills to develop a television segment, newspaper article/advertisement, } \\
\text { web site and/or public address (PA) announcements } \\
\text { - Increase awareness of lower-fat options available in school cafeterias and vending machines } \\
\text { - Feature stories in school newspapers, web-site development and school TV information spots }\end{array}$ \\
\hline Self-assessment surveys & $\begin{array}{l}\text { Provided students with opportunity to assess diet } \\
\text { - Students identified foods they typically choose from their cafeteria and vending machines } \\
\text { - Ideas for healthy, lower-fat options were provided on the survey } \\
\text { - Coupons provided for a food sample }\end{array}$ \\
\hline Taste-testing & $\begin{array}{l}\text { Allowed students to taste lower-fat foods offered in the school cafeteria } \\
\text { - Lower-fat food samples distributed to students } \\
\text { - Developed nutrition surveys to compare the nutritional content of the regular and lower-fat versions } \\
\text { of foods }\end{array}$ \\
\hline Fruit and vegetable & $\begin{array}{l}\text { Provided opportunity to taste fresh fruit and vegetables } \\
\text { - Improve students' attitudes towards fruit and vegetables } \\
\text { - Increase selection of fruit and vegetables in school cafeteria } \\
\text { - Promotions included apple, kiwi, pineapple, honeydew, cantaloupe, carrot/pea pod/jicama medley, } \\
\text { and a strawberry-yoghurt parfait }\end{array}$ \\
\hline Public service announcements & $\begin{array}{l}\text { Provided opportunity to apply video/TV production and/or camera skills to develop school-wide } \\
\text { public service announcements to increase awareness of project and promote fruit and vegetable } \\
\text { consumption } \\
\text { - Developed a script and shoot sheet, and made contacts for influential spokespeople } \\
\text { - 'Actors' were filmed or photographed promoting the lower-fat food for an ad to be played on school } \\
\text { television or hung on posters displayed in school }\end{array}$ \\
\hline Poster contest & $\begin{array}{l}\text { Provided the opportunity to create posters promoting a healthy diet } \\
\text { - Marketing method to increase sales of lower-fat foods in the cafeteria } \\
\text { - Students created promotional posters } \\
\text { - Students and food-service staff voted for favourite designs } \\
\text { - Winners' posters hung inside the cafeteria } \\
\text { - Group conducted survey to determine exposure of posters }\end{array}$ \\
\hline Raffle event & $\begin{array}{l}\text { A 2-week raffle event targeting the lower-fat foods in school cafeteria } \\
\text { - Students who purchased lower-fat foods turned in wrappers in exchange for a ticket } \\
\text { - Drawing of tickets took place in which prizes were raffled out }\end{array}$ \\
\hline T-shirt contest & $\begin{array}{l}\text { Provide opportunity to create messages that promote a healthy, lower-fat diet, and encourage } \\
\text { students to adopt healthy eating behaviours } \\
\text { - Students created T-shirts promoting eating and/or purchasing of lower-fat foods } \\
\text { - Students, faculty and/or food-service staff vote for favourite designs } \\
\text { - Winning T-shirts worn by food-service staff or displayed in school } \\
\text { - Students with winning designs received gift certificates }\end{array}$ \\
\hline Recipe creations & $\begin{array}{l}\text { Provided opportunity to develop a new healthy, lower-fat recipe to be served in the cafeteria } \\
\text { - Student groups worked with food-service staff to develop, promote, taste-test and sell the new lower-fat } \\
\text { foods in the cafeteria }\end{array}$ \\
\hline Promotional campaigns & $\begin{array}{l}\text { Campaigns to increase student purchases of lower-fat food items in school through student participation } \\
\text { and involvement in planning } \\
\text { - Develop, implement and evaluate projects for overall marketing campaign } \\
\text { - Promotional activities measured by sales data, student survey analysis and process evaluation } \\
\text { measures }\end{array}$ \\
\hline Create your own promotion & $\begin{array}{l}\text { Provided opportunity to develop a promotion tailored to school's needs } \\
\text { - Students draft a proposal for the creation of a new promotion and implement it school-wide }\end{array}$ \\
\hline Challenge game & $\begin{array}{l}\text { Provided students with opportunity to market and advertise the benefits of eating lower-fat foods to their } \\
\text { peers } \\
\text { - Student group develops a list of the 'Top Ten Reasons for Eating Lower-fat Foods' and shares reasons } \\
\text { with student body through use of posters, PA announcements, newspaper and/or television } \\
\text { advertisements }\end{array}$ \\
\hline Student survey & $\begin{array}{l}\text { Provided opportunity to determine what factors influence their peers' food choices, and to see how } \\
\text { students think about lower-fat foods } \\
\text { - Surveys distributed to students at lunch period or homeroom } \\
\text { - Student group tallies information and creates summary report for TACOS staff }\end{array}$ \\
\hline Coupon kick-off & $\begin{array}{l}\text { Food-service staff selected items to be highlighted for this promotion } \\
\text { - Students and staff received a coupon good for one lower-fat item in the cafeteria } \\
\text { - First event at each school for both Year } 1 \text { and Year } 2\end{array}$ \\
\hline $\begin{array}{l}\text { Newspaper advertisements } \\
\text { Informational flier }\end{array}$ & $\begin{array}{l}\text { TACOS staff purchased newspaper ads in school newspapers to highlight study goals and events } \\
\text { Provided schools with information about the TACOS study in a flier }\end{array}$ \\
\hline
\end{tabular}

TACOS-Trying Alternative Cafeteria Options in Schools. 
Table 3 Number of student groups/classes who participated in promotional activities

\begin{tabular}{|c|c|c|c|}
\hline & $\frac{\text { Year } 1}{n(\%)}$ & $\frac{\text { Year } 2}{n(\%)}$ & $\begin{array}{l}\text { Total } \\
n(\%)\end{array}$ \\
\hline Health classes & $8(26)$ & $19(25)$ & $27(25)$ \\
\hline Marketing/business classes & $6(19)$ & $15(20)$ & $21(21)$ \\
\hline Student council & $3(10)$ & $9(12)$ & $12(11)$ \\
\hline $\begin{array}{l}\text { Marketing group } \\
\text { (DECA)/Business } \\
\text { Professionals of America }\end{array}$ & $2(6)$ & $4(5)$ & $6(6)$ \\
\hline $\begin{array}{l}\text { Family and consumer } \\
\text { science (FCS) classes }\end{array}$ & $3(10)$ & $2(3)$ & $5(5)$ \\
\hline $\begin{array}{l}\text { Other student groups/classes } \\
\text { (student newspaper staff, } \\
\text { leadership class, physical } \\
\text { education class, English } \\
\text { class, drama group) }\end{array}$ & $9(29)$ & $27(35)$ & $36(33)$ \\
\hline Total & 31 & 76 & 107 \\
\hline
\end{tabular}

facilitated and supervised by at least one trained research staff member. The Promotions Co-ordinator trained and supervised six graduate assistants to conduct/facilitate promotions in the 10 schools and collect process evaluation data. Supervision of students was conducted in four steps. First, the project goals and options for promotional activities were reviewed with the students, and the students discussed which type of promotional activities were most interesting and practical for their school. Second, students selected a promotional activity, and decisions were made regarding the timing of the promotion, the collaborators that were necessary (e.g. food-service staff) and development of materials. Third, students developed their materials and TACOS staff reviewed all products before the promotional activity was implemented. During the entire process, TACOS staff were in contact with students to ensure that the students were on track with their activities and to give support when needed. Fourth, following the promotional activity, TACOS staff met with students to discuss the evaluation findings of the promotional activity.

\section{Food-service staff}

Food-service staff consisted of food-service directors, cook/managers, cooks and cashiers. The main role for food-service staff in the TACOS study was to offer more lower-fat foods in the school cafeteria, which was an ongoing process over the course of the two-year study $^{27,30}$. Food-service staff from the 10 intervention schools also participated in promotions of lower-fat foods by assisting TACOS staff and student promoters with taste tests and helping student groups with student-led promotions

\section{Implementation of promotions}

Activities were implemented at various places and times throughout the school year such as in classrooms as a class activity, in the cafeteria as a lunchtime activity, or during homeroom or advisory periods.

\section{Measurements}

Data collection was conducted throughout the two years of the study (August 2000-June 2002). Computerised, point-of-sale, à la carte sales data were collected via mail or email from food-service staff on a weekly basis during the academic school years. Promotional activity data were collected by TACOS staff continuously as activities were implemented. The study was approved by the Human Subjects Review Board at the University of Minnesota.

\section{Promotions}

The following information was collected by TACOS research staff for each promotional activity in the schools: source of each promotion (research staff, student group and/or food-service staff), type of promotion, date of promotion, and duration of promotion. For student-led promotions (i.e. promotions that were led by the students with assistance from research and/or food-service staff), data were also collected regarding the number of students trained to implement the promotion, and the amount of the financial incentive given to the student group for conducting the promotion. All promotion variables were summarised at the school level. Two main independent variables for analysis included the number of promotions conducted per year and the duration of promotions per year.

\section{À la carte cafeteria sales}

Sales data on à la carte foods were collected on a weekly basis in electronic format from food-service staff in each school. Lower-fat foods were defined as those having $\leq 5 \mathrm{~g}$ of fat per serving. To separately track lower-fat and higher-fat food sales, cash register keypad overlays were modified prior to the beginning of the school year to ensure that higher-fat and lower-fat food items were keyed on separate keys; details have been published previously ${ }^{27}$. Two primary outcome measures regarding à la carte lower-fat foods sales were calculated from the school means of weekly à la carte sales data: average level of percentage lower-fat sales and slope of percentage lowerfat sales. The average level of percentage lower-fat sales for each school was determined by dividing the number of sales of lower-fat foods by the total number of food sales for each week's sales. The slope of percentage lower-fat sales reflects the change in percentage lower-fat sales over time.

\section{Data analysis}

The data are school-level, and thus consists of 10 data points (school means). Descriptive analyses examined the number of total promotions conducted, the duration of all of the promotions, and the source of the promotions. Regression analyses were performed with year-specific outcomes of either the average percentage of lower-fat à la carte sales or the annual slope of percentage lower-fat à la carte sales. Promotional activity data (number and 
duration of all activities regardless of source) were the independent variables in separate equations. Adjustment was made for one school-level covariate as a measure of school-wide social disadvantage: the percentage of the student body eligible for free/reduced lunch. With only 10 data points, the possibility exists that any particular datum may have disproportionate influence on the regression fit. To counter this, iterative robust regression was performed in which any school with a large residual from the regression fit was down-weighted ${ }^{31}$. Robust regression is unbiased if differences between weights for variables in an analysis are kept at a maximum of about 4:1; therefore, differences between weights were not allowed to exceed 3.2:1. The resultant regression fit is not liable to be biased by an aberrant school datum. All analyses were conducted using $\mathrm{SAS}^{32}$.

\section{Results}

\section{Description of promotions conducted}

Coupon kick-off promotions were conducted at all 10 schools at the beginning of Year 1 and Year 2 to establish the presence of TACOS and give positive name recognition in each school, as well as to give students an opportunity to try a lower-fat snack.

The number and types of all promotional activities conducted in the TACOS programme by source and year are presented in Table 4. In Year 1, 49 promotions were conducted at the 10 schools. Sixty-three per cent of the promotions involved student groups, 29\% were conducted by TACOS staff only, and $8 \%$ were conducted by TACOS staff and food-service personnel. Taste tests and coupon distributions were the most common promotional activities implemented in Year 1. The mean number of promotions conducted was 4.9 per school (standard deviation (SD) 1.5). Most of the promotions were 1 day or 2-3 days in duration (range 1 to 16-20 days). An average of 56 students per school were trained for active participation in promotional activities over the course of Year 1 activities (SD 47, range 8-130), with a mean of 11 students trained per intervention activity (SD 7 , range $3-22$ ).

In Year 2, 132 promotions were conducted at the 10 schools. Fifty-eight per cent of the promotions involved student groups, $25 \%$ were conducted by TACOS staff only, and $17 \%$ were conducted by TACOS staff and food-service personnel. The mean number of promotions conducted was 13.2 per school (SD 3.3). A main focus of the intervention during Year 2 was on the promotion of fruits and vegetables. Fruit and vegetable promotions, newspaper advertisements, coupon distributions and student self-assessment activities were the most common promotional activities in Year 2. Most of the promotions were 1 day or 4-5 days in duration (range 1 to $21+$ days). An average of 141 students per school were trained for active participation in promotional activities over the course of Year 2 (SD 174, range 18-500), with a mean of nine students trained per intervention activity (SD 10, range $2-31$ ).

\section{Student-led promotions}

As shown in Table 2, across the two years, students from health classes, marketing/business classes and the student council were the most active in taking leadership responsibilities for student promotions. In Year 1, students most commonly implemented promotional activities involving taste-testing, student surveys and contest/game activities. Students implemented an average of 3.1 promotions per school (SD 1.4). Financial incentives ranged from $\$ 50$ to 300 per promotion (mean $\$ 162$, SD $\$ 38$ ), and the mean amount of financial incentives per school was \$418 (SD \$276).

In Year 2, the activity most frequently implemented by students was promotion of fruits and vegetables due to the focus on fruits and vegetables in the intervention programme as a whole during Year 2. Other common student-led promotional activities in Year 2 included selfassessments, media health campaigns, unique promotions created by students, and public service announcements. Students implemented an average of 7.6 promotions (SD 2.4). Financial incentives ranged from $\$ 25$ to 300 per promotion (mean \$130, SD \$15.8), and the average total amount of financial incentives per school was $\$ 920$ (SD \$320).

\section{Associations between promotions and à la carte food sales}

As shown in Fig. 1, the number of total promotions conducted in schools was significantly associated with an increase in the slope of percentage lower-fat food sales in Year $1(P=0.033)$, but not in Year $2(P=0.399)$. The number of total promotions and the average level of percentage lower-fat food sales were marginally positively related in Year $1(P=0.057)$, but not in Year $2(P=0.443)$. The duration of total promotions and the slope of percentage lower-fat food sales were unrelated in Year 1 $(P=0.207)$, but significantly positively associated in Year $2(P=0.029)$. The duration of total promotions and the average level of percentage lower-fat food sales were marginally positively related in Year $1(P=0.065)$, but not in Year $2(P=0.164)$.

\section{Discussion}

The purpose of the present study was to describe the number and types of promotional activities, particularly student-led, for lower-fat foods in à la carte areas in secondary school cafeterias, and the associations between total promotional activities and sales of lower-fat foods. The results showed that the combined efforts of TACOS staff, food-service staff, teacher/faculty liaisons and students were effective in implementing 181 promotional activities over two years. The number of total promotions 
Table 4 Number and types of TACOS promotional activities by source by year

\begin{tabular}{|c|c|c|c|}
\hline Source of promotions & $\begin{array}{c}\text { Number of } \\
\text { promotions conducted }\end{array}$ & $\begin{array}{l}\text { Types of promotions } \\
\text { implemented }\end{array}$ & $n$ \\
\hline \multicolumn{4}{|l|}{ Year 1} \\
\hline \multirow[t]{8}{*}{ Students \& TACOS staff } & \multirow[t]{8}{*}{30} & Taste-testing & 8 \\
\hline & & Student survey & 6 \\
\hline & & Challenge game & 4 \\
\hline & & Coupon distributions & 3 \\
\hline & & Media campaign & 3 \\
\hline & & Create your own promotion & 3 \\
\hline & & Raffle event & $\begin{array}{l}2 \\
1\end{array}$ \\
\hline & & Other & \\
\hline Students/food-service/TACOS staff & 1 & Coupon distribution & 1 \\
\hline Food-service \& TACOS staff & 4 & Coupon distribution & 4 \\
\hline \multirow[t]{4}{*}{ TACOS staff only } & \multirow[t]{4}{*}{14} & Taste-testing & 6 \\
\hline & & Informational flier & 4 \\
\hline & & Coupon distribution & 2 \\
\hline & & Other & 2 \\
\hline \multirow[t]{9}{*}{ Year 1 total } & \multirow[t]{9}{*}{49} & Taste-testing & 14 \\
\hline & & Coupon distribution & 10 \\
\hline & & Student survey & 6 \\
\hline & & Challenge game & 4 \\
\hline & & Informational flier & 4 \\
\hline & & Media campaign & 3 \\
\hline & & Create your own promotion & 3 \\
\hline & & Raffle event & 2 \\
\hline & & Other & 3 \\
\hline \multicolumn{4}{|l|}{ Year 2} \\
\hline \multirow[t]{10}{*}{ Students \& TACOS staff } & \multirow[t]{10}{*}{44} & Media campaign & 9 \\
\hline & & Self-assessment & 10 \\
\hline & & Create your own promotion & 7 \\
\hline & & Public service announcement & 7 \\
\hline & & Poster contest & 3 \\
\hline & & Raffle event & 2 \\
\hline & & Promotional campaign & 2 \\
\hline & & Fruit \& vegetable & 2 \\
\hline & & T-shirt contest & 1 \\
\hline & & Other & 1 \\
\hline \multirow[t]{5}{*}{ Students/food-service/TACOS staff } & \multirow[t]{5}{*}{32} & Fruit \& vegetable & 25 \\
\hline & & Self-assessment & 3 \\
\hline & & Taste-testing & 2 \\
\hline & & Recipe creations & 1 \\
\hline & & Create your own promotion & 1 \\
\hline \multirow[t]{2}{*}{ Food-service \& TACOS staff } & \multirow[t]{2}{*}{23} & Fruit \& vegetable & 13 \\
\hline & & Coupon distribution & 10 \\
\hline \multirow[t]{3}{*}{ TACOS staff only } & \multirow[t]{3}{*}{33} & Newspaper advertisements & 31 \\
\hline & & Taste-testing & 1 \\
\hline & & Informational flier & 1 \\
\hline \multirow[t]{15}{*}{ Year 2 total } & 132 & Fruit \& vegetables & 40 \\
\hline & & Newspaper advertisements & 31 \\
\hline & & Coupon distribution & 10 \\
\hline & & Self-assessment & 13 \\
\hline & & Media campaign & 9 \\
\hline & & Create your own promotion & 8 \\
\hline & & Public service announcements & 7 \\
\hline & & Taste-testing & 3 \\
\hline & & Poster contest & 3 \\
\hline & & Raffle event & 2 \\
\hline & & Promotional campaign & 2 \\
\hline & & Recipe creations & 1 \\
\hline & & T-shirt contest & 1 \\
\hline & & Informational flier & 1 \\
\hline & & Other & 1 \\
\hline
\end{tabular}

TACOS-Trying Alternative Cafeteria Options in Schools.

was significantly related to sales of lower-fat à la carte foods in schools in Year 1, and the duration of total promotions was significantly related to sales of lower-fat foods in Year 2.
The significant positive associations between the slope of percentage lower-fat food sales and the number of total promotions in Year 1 and the duration of total promotions in Year 2 indicate that perhaps the novel aspects or 

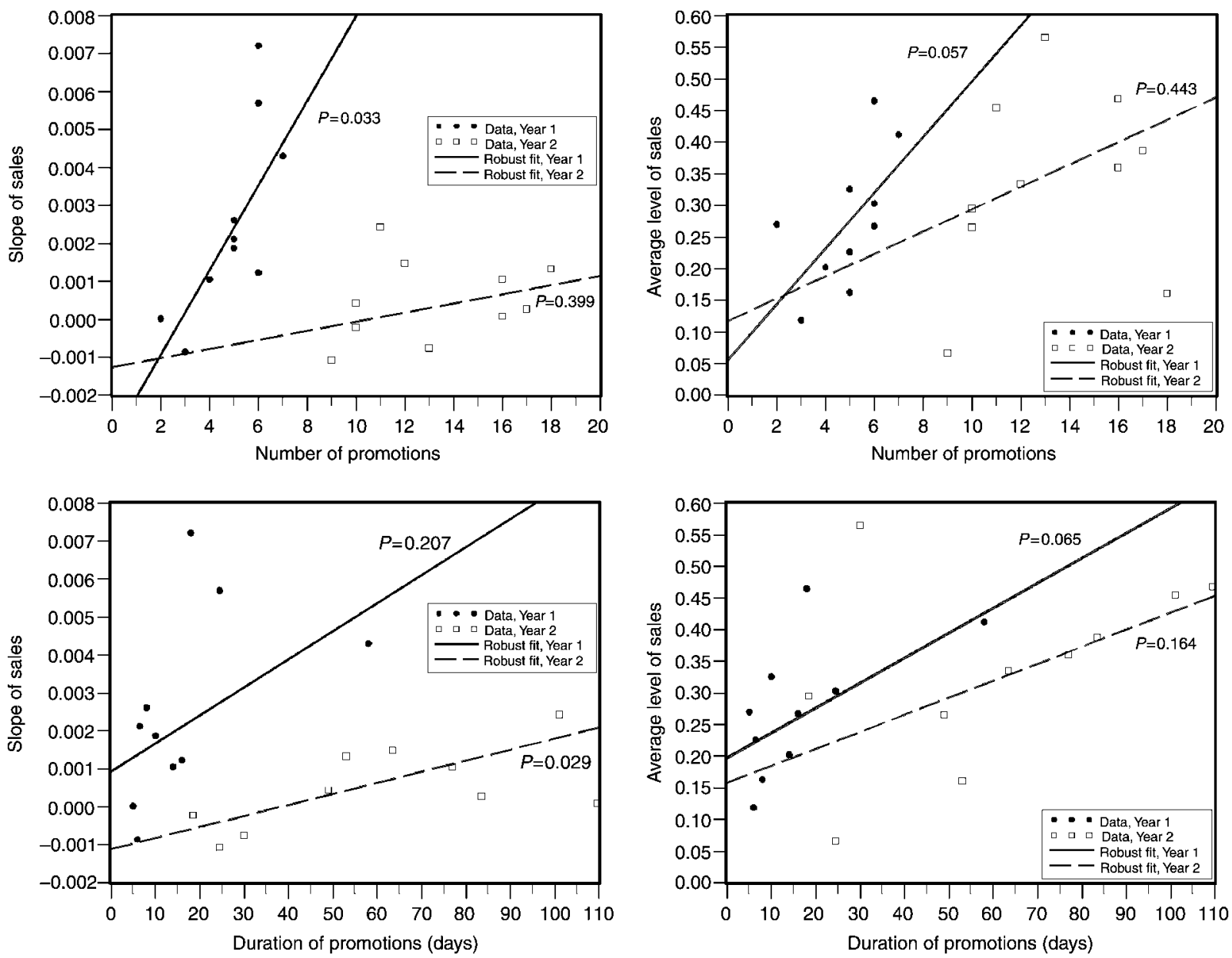

Fig. 1 Slope and average percentage level of lower-fat food sales by the number and duration of promotional activities

initiation of promotional activities were more influential on the change in percentage lower-fat food sales at the beginning of the study. However, by the second year, the duration of the promotions played a more influential role than the number of promotions in the sales of lower-fat foods. These findings suggest that implementing a greater number of promotions in the initial year followed by promotions of longer duration may increase the sales of lower-fat foods in à la carte areas of school cafeterias. It was expected that the increase in the number of promotions during Year 2 would lead to a more dramatic increase in sales of lower-fat foods. Perhaps the foods promoted in Year 2 were not as well-liked by the students, were less available in the school cafeteria or were less novel, and subsequently fewer were purchased.

The increase in the number of promotions from the first year to the second year of the study indicates that sufficient time and staffing are necessary to recruit student groups by increasing awareness of the promotions programme among school personnel and students. A full-time promotions co-ordinator was necessary. Our experiences are consistent with previous health promotion programmes $^{33}$ that have shown that it is important to have close contact between study staff and school staff in order to implement promotional activities. Study co-ordinators must have special skills in flexibility and communication in order to gain teacher and faculty interest and involvement, and to ensure project acceptance and facilitation.

The feasibility and success of student promotional activities in the schools were influenced by four main factors:

1. school administration support and enthusiasm for the activities;

2. similar goals between the project and the student group or class;

3. support of school food-service staff; and

4. teachers' perceptions that the project was worthwhile, and their facilitation of the activities.

Completion of student-led promotions was possible with a moderate degree of both structure and adult supervision. The goal of having adults primarily act as facilitators to student-led efforts was successful, with students leading more than half of the promotional activities. However, particularly at the beginning of the study, research staff found it necessary to implement promotional activities to cultivate school-wide awareness of the intervention programme. The continuous oversight 
of student work by project staff via telephone consultation and site visits was similar to that in other projects working with adolescents to change their environment ${ }^{34}$. Oversight by adult volunteers and/or study staff was essential. Secondary school students need guidance from staff on achieving promotion goals, allocating responsibilities and developing timelines.

Monetary incentives for students were a component of the TACOS study and played a role in motivating student groups to participate in promotional activities. Little empirical research has been conducted to evaluate the role of incentives in adolescent health behaviour research. Two studies have reported on the influence of monetary incentives in recruitment of adolescents for health behaviour intervention programmes, one for a smokingrelated intervention programme ${ }^{35}$ and the other for an adolescent pregnancy intervention programme ${ }^{36}$. Both of these studies found that monetary incentives increased programme participation. In the present study, we did not test the effects of the monetary incentives; however, as with the studies mentioned above, incentives did appear to be a motivating factor for student group participation in the promotional activities. Financial incentives in schoolbased programmes may not be feasible. A non-financial incentive such as course credit may be a suitable alternative.

The findings from the present study indicate that students are interested in implementing nutrition-related promotional activities. Students from health classes, marketing/business classes and the student council were particularly interested in working in groups to carry out promotional activities. Students especially enjoyed the promotions related to food sampling and taste-testing, the nutrition self-assessments, and the poster contest activities. The media campaign activities were popular and received a high level of exposure through the school newspaper. Activities such as the raffle event and challenge game were not as successful because students perceived them as too tedious to complete.

The promotional activities also facilitated positive interactions between students, adult liaisons and foodservice staff. Each group learned more about the others, and they worked well together to promote lower-fat foods in their schools. This team approach of collaborative efforts of TACOS staff, food-service staff, liaisons and students capitalises on a delivery approach that incorporates volunteers, peers and subject-matter experts. The adult faculty members in the present study played a similar role to adult volunteers in alcohol reduction programmes ${ }^{34}$ in which they supported the students' efforts, but with limited time and resources. In all of the peer-led health behaviour change programmes ${ }^{4,5,34}$, students are often the most visible interventionists and they play a unique role in changing behaviour norms. Study staff are usually the content experts and supply the expertise necessary for education materials and oversight of the promotional activities. This type of model has been found to be effective in other peer health education programmes ${ }^{3}$.

There were several barriers to recruiting students and school faculty advisors. In general, students were very busy and already committed to many activities. Therefore, it was necessary to identify the goals of the existing student groups/classes and fit the promotional activities within the group's framework. For instance, the promotional activities helped the drama group increase their visibility, and became an important funding source. Similarly, the marketing/business group proved to be a previously untapped, excellent resource for promoting lower-fat foods in the schools since their goal was to learn how to market products. Barriers to recruiting school faculty advisors were primarily related to the faculty's perception that participation in the development and implementation of activities would be too timeconsuming.

Several strengths of the present study deserve mention. Over half of the promotions involved students and each intervention school conducted at least 12 promotions over two years. It should be noted that the large number of fruit and vegetable promotions implemented in Year 2 were primarily due to the focus of the intervention plan rather than by student initiative. The application of the peer promotions model to school food choices is novel; many nutrition interventions are solely educational. The main outcome measure of lower-fat food sales was an objective measure of sales, collected by computerised point-of-sales software rather than self-reported sales by food-service personnel. Another strength was the extensive, detailed data collected regarding the promotional activities.

One of the limitations of the present study is in regard to the power of the analyses. The promotional activity data were analysed with schools as the unit of analysis, which resulted in only 10 data points. There may not have been enough power to identify differences in sales of lower-fat foods by the number and duration of promotions. Also, the weighting process in robust regression allowed some flexibility that affected the significance of the findings. We used conservative weighting so that influential outliers did not unduly influence the analysis; however, determining the level of their influence was relatively arbitrary. Another limitation was that the food promotions targeted specific lower-fat foods, such as fruits and vegetables or baked chips, while the sales data (percentage lower-fat) included a large number of different lower-fat foods that were averaged over time. Therefore, it cannot be shown that a specific promotion targeting a specific food showed increases in sales of that product. In addition, the effects of the food promotions on the sales data cannot be separated from the effects of the other TACOS intervention components, such as the increased availability of lower-fat foods in the cafeterias. Finally, the amount of staffing and support needed for the TACOS student-led 
promotions programme was large and financial incentives were used to recruit student groups. Schools may not have the financial resources or staffing to complete the types of promotions that were implemented in the present study.

In summary, promotions for lower-fat food choices in à la carte areas of secondary school cafeterias can be implemented effectively in schools through collaborations between students, school food-service staff and research staff. Such promotions may increase sales of lower-fat foods in the à la carte areas of the school cafeteria.

\section{Acknowledgements}

The authors would like to thank William Baker for his expertise in database management and graphics presentation. Funding for this project was supported by NIH/R18 HL61305 and supplemented by funding from the Centers for Disease Control and Prevention.

\section{References}

1 Komro KA, Perry CL, Veblen-Mortenson S, Williams CL. Peer participation in Project Northland: a community-wide alcohol use prevention project. Journal of School Health 1994; 64: 318-22.

2 Komro KA, Perry CL, Murray DM, Veblen-Mortenson S, Williams CL, Anstine PS. Peer-planned social activities for preventing alcohol use among young adolescents. Journal of School Health 1996; 66: 328-34.

3 Black DR, Tobler NS, Sciacca JP. Peer helping/involvement: an efficacious way to meet the challenge of reducing alcohol, tobacco, and other drug use among youth. Journal of School Health 1998; 68: 87-93.

4 Goldberg L, MacKinnon DP, Elliot DL, Moe EL, Clarke G, Cheong $\mathrm{J}$. The adolescents training and learning to avoid steroids program: preventing drug use and promoting health behaviors. Archives of Pediatric E Adolescent Medicine 2000; 154: 332-8.

5 Fors SW, Jarvis S. Evaluation of a peer-led drug abuse risk reduction project for runaway/homeless youths. Journal of Drug Education 1995; 25: 321-33.

6 Ozer EJ, Weinstein RS, Maslach C, Siegel D. Adolescent AIDS prevention in context: the impact of peer educator qualities and classroom environments on intervention efficacy. American Journal of Community Psychology 1997; 25: 289-323.

7 Orpinas P, Kelder S, Frankowski R, Murray N, Zhang Q, McAlister A. Outcome evaluation of a multi-component violence-prevention program for middle schools: the Students for Peace project. Health Education Research 2000; 15: 45-58.

8 Bandura A. Social Learning Theory. Englewood Cliffs, NJ: Prentice-Hall, Inc., 1977.

9 Bandura A. Social Foundation of Thought and Action. Englewood Cliffs, NJ: Prentice Hall, Inc., 1986.

10 Dusenburg L, Falco M. Eleven components of effective drug abuse prevention curricula. Journal of School Health 1995; 65: 420-5.

11 Perry CL. Preadolescent and adolescent influences and health. In: Smedley BD, Syme SL, eds. Promoting Health: Intervention Strategies from Social and Behavioral Research. Washington, DC: National Academy Press, 2001.

12 Mellanby AR, Rees JB, Tripp JH. Peer-led and adult-led school health education: a critical review of available comparative research. Health Education Research 2000; 15: $533-45$

13 Mellanby AR, Newcombe RG, Rees J, Tripp JH. A comparative study of peer-led and adult-led school sex education. Health Education Research 2001; 16: 481-92.

14 Perry CL, Grant M. Comparing peer-led to teacher-led youth alcohol education in four countries. Alcohol Health $\&$ Research World 1998; 12: 322-6.

15 Klepp K-I, Halper A, Perry CL. The efficacy of peer leaders in drug abuse prevention. Journal of School Health 1986; 56: 407-11.

16 Perry CL. Prevention of alcohol use and abuse in adolescence: teacher vs. peer-led intervention. Crisis 1989; 10: $52-61$.

17 Komro KA, Perry CL, Veblen-Mortenson S, Williams CL, Roel JP. Peer leadership in school and community alcohol use prevention activities. Journal of Health Education 1999; 30: 202-8.

18 Contento L, Balch G, Bronner Y, Lytle LA, Maloney SK, Olson CM, Swadenei SS. The effectiveness of nutrition education and implications for nutrition education policy, programs and research: a review of research. Journal of Nutrition Education 1995; 27: 284-418.

19 Luepker RV, Perry CL, McKinlay SM, Nader PR, Parcel GS, Stone EJ, et al. Outcomes of a field trial to improve children's dietary patterns and physical activity. The Child and Adolescent Trial for Cardiovascular Health. CATCH collaborative group. Journal of the American Medical Association 1996; 275: 768-76.

20 Snyder MP, Story M, Trenkner LL. Reducing fat and sodium in school lunch programs: The LUNCHPOWER! Intervention Study. Journal of the American Dietetic Association 1992; 92: 1087-91.

21 Arbeit ML, Johnson CC, Mott DS, Harsha DW, Nicklas TA, Webber LS, et al. The Heart Smart cardiovascular school health promotion: behavior correlates of risk factor change. Preventive Medicine 1992; 21: 18-32.

22 Story M, Mays RW, Bishop DB, Perry CL, Taylor G, Smyth M, et al. 5-a-day Power Plus: process evaluation of a multicomponent elementary school program to increase fruit and vegetable consumption. Health Education $\varepsilon$ Behavior 2000; 27: 187-200.

23 Story M, Lytle LA, Birnbaum AS, Perry CL. Peer-led, schoolbased nutrition education for young adolescents: feasibility and process evaluation of the TEENS study. Journal of School Health 2002; 72: 121-7.

24 Agron P, Takada E, Purcell A. California Project LEAN's Food on the Run Program: an evaluation of a high school-based student advocacy nutrition and physical activity program. Journal of the American Dietetic Association 2002; 102: S103-5.

25 Perez-Rodrigo C, Aranceta J. School-based nutrition education: lessons learned and new perspectives. Public Health Nutrition 2001; 4: 131-9.

26 Monge-Rojas R, Nunez HP, Garita C, Chen-Mok M. Psychosocial aspects of Costa Rican adolescents' eating and physical activity patterns. Journal of Adolescent Health 2002; 31: 212-9.

27 French SA, Story M, Fulkerson JA, Hannan P. An environmental intervention to promote lower fat food choices in secondary schools: outcomes from the TACOS study. American Journal of Public Health 2004; in press.

28 US Department of Agriculture. National school lunch program and school breakfast program nutrition objectives for school meals (TCFR 210.220). Federal Register 10 June 1994; 30218-51.

29 Story M, Neumark-Sztainer D. School-based nutrition education programs and services for adolescents. Adolescent Medicine 1996; 7: 287-302.

30 French S, Story M, Fulkerson JA, Gerlach AF. Food 
environment in secondary schools: à la carte, vending machines, food policies and practices. American Journal of Public Health 2003; 93: 1161-7.

31 Holland PW, Weloch RE. Robust regression using interatively reweighted least squares. Communications Statistics: Theory and Methods 1977; 6: 813-27.

32 SAS Institute, Inc. SAS User's Guide: Statistics, 8th version Cary, NC: SAS Institute, Inc., 1999.

33 Backett-Milburn K, Wilson S. Understanding peer education: insights from a process evaluation. Health Education Research 2000; 15: 85-96.

34 Lachter RB, Komro KA, Veblen-Mortenson S, Perry CL, Williams CL. High school students' efforts to reduce alcohol use in their communities: Project Northland's youth development component. Journal of Health Education 1999; 30: 330-42.

35 Martinson BC, Lazovich D, Lando HA, Perry CL, McGovern PG, Boyle RG. Effectiveness of monetary incentives for recruiting adolescents to an intervention trial to reduce smoking. Preventive Medicine 2000; 31: 706-13.

36 Stevens-Simon C, Dolgan JI, Kelly L, Singer D. The effect of monetary incentives and peer support groups on repeat adolescent pregnancies. A randomized trial of the Dollar-aDay Program. Journal of the American Medical Association 1997; 277: 977-82. 